\title{
Differential Expression in Glioblastoma Multiforme and Cerebral Hemangioblastoma of Cytoplasmic Proteins That Bind Two Different Domains within the 3'-Untranslated Region of the Human Glucose Transporter 1 (GLUT1) Messenger RNA
}

\author{
Haruhisa Tsukamoto, Ruben J. Boado, and William M. Pardridge \\ Department of Medicine, UCLA School of Medicine, Los Angeles, California 90095-1682
}

\begin{abstract}
The glucose transporter 1 (GLUT1) protein is underexpressed in human glioblastoma multiforme and is overexpressed in human cerebral hemangioblastoma. To gain insight into possible posttranscriptional mechanisms regulating the expression of the GLUT1 protein in human brain tumors, cytosolic proteins were prepared from these two tumors and used in RNase T1 protection assays that employed [ $\left.{ }^{32} \mathrm{P}\right]$ human GLUT1 synthetic RNA prepared from transcription plasmids. Gel shift mobility assays and ultraviolet light cross-linking studies demonstrated the formation of specific RNA/protein complexes that migrated with a mol mass of 120,44 , and $41 \mathrm{kD}$. RNase T1 mapping and oligodeoxynucleotide competition studies showed that the $120 \mathrm{kD}$ complex was comprised of an RNA fragment that localized to nucleotides 2186-2203 of the GLUT1 mRNA. The $44 \mathrm{kD}$ complex contained an adenosine-uridine-rich RNA fragment that localized to nucleotides 1885-1906 of the human GLUT1 mRNA, and the formation of this complex was inhibited by synthetic RNA enriched in adenosineuridine sequences. The $44 \mathrm{kD}$ complex was selectively downregulated in hemangioblastoma as compared to glioblastoma multiforme. These studies demonstrate that human brain tumors have differential regulation of cytosolic proteins that specifically interact with two different domains in the $3^{\prime}$-untranslated region of the GLUT1 mRNA, which may serve to mediate the posttranscriptional regulation of GLUT1 gene expression in these tumors. (J. Clin. Invest. 1996. 97:2823-2832.) Key words: brain tumor • blood-brain barrier • ribonuclease $\bullet$ messenger RNA stability - exonuclease
\end{abstract}

\section{Introduction}

The glucose transporter 1 (GLUT1) ${ }^{1}$ is differentially regulated in human brain tumors. GLUT1 mRNA levels increase with the degree of glioma malignancy $(1,2)$, while the immunoreactive GLUT1 protein decreases as the tumor grade increases (3-5). Conversely, in human cerebral hemangioblastoma, the

Address correspondence to William M. Pardridge, Department of Medicine, UCLA School of Medicine, Los Angeles, CA 90095-1682. Phone: 310-825-8858; FAX: 310-206-5163; E-mail: wpardrid@med1. medsch.ucla.edu

Received for publication 16 October 1995 and accepted in revised form 4 April 1996.

J. Clin. Invest.

(C) The American Society for Clinical Investigation, Inc.

0021-9738/96/06/2823/10 \$2.00

Volume 97, Number 12, June 1996, 2823-2832
GLUT1 immunoreactive protein is markedly upregulated (6). The measurement of the immunoreactive GLUT1 protein and the GLUT1 mRNA in pathophysiologic states, such as brain tumors, experimental diabetes, glucose deprivation, and development indicates the principle mode of regulation of GLUT1 gene expression in these states is at the posttranscriptional level (7). Recent studies demonstrate that C6 rat glioma cytosolic fractions contain at least two proteins that react with specific sequences within the GLUT1 mRNA 3'-untranslated region (UTR) (8). These findings are consistent with other studies showing that cytosolic transacting factors bind specifically to cis-regulatory elements within either the $5^{\prime}$ - or the $3^{\prime}$ UTR of mRNAs to regulate mRNA stability and/or translational efficiency (9-11).

Since rat glioma cells contain cytosolic proteins that react with the GLUT1 mRNA 3'-UTR (8), and since human brain tumors, such as hemangioblastoma (11) and glioblastoma multiforme $(1,2)$ exhibit divergent regulation of GLUT1 protein, the present studies test the hypothesis that differential cis-/ trans-interactions exist between cytosolic proteins in these two human brain tumors and the human GLUT1 mRNA. These studies use a transcription plasmid to generate full-length human GLUT1 mRNA and use cytosolic proteins obtained from human glioblastoma multiforme or hemangioblastoma in RNase T1 protection assays using gel shift mobility studies, ultraviolet light (UV) cross-linking, and RNase T1 mapping.

\section{Methods}

Materials. Restriction endonuclease XbaI, proteinase K, and RNA polymerase T7, were purchased from Stratagene Inc. (La Jolla, CA). RNase T1 and RNA molecular weight size ladder $(0.24-9.5 \mathrm{~kb})$ were obtained from GIBCO BRL (Gaithersburg, MD). Restriction endonuclease SspI, RNase-free DNase I, and Sephadex G-25 spin column were purchased from Boehringer Mannheim Biochemicals (Indianapolis, IN). Restriction endonuclease HindIII and stop solution (No. 70724) were obtained from United States Biochemical Corp. (Cleveland, $\mathrm{OH})$. Restriction endonuclease EcoRI was purchased from New England Biolabs Inc. (Beverly, MA). All nucleotide triphosphates and oligonucleotide sizing markers (8-32 bases) were purchased from Pharmacia LKB Biotechnology Inc. (Piscataway, NJ). $\left[\alpha^{32} \mathrm{P}\right]$ ATP $(800 \mathrm{Ci} / \mathrm{mmol})$ and $\left[\gamma^{32} \mathrm{P}\right]$ ATP $(3,000 \mathrm{Ci} / \mathrm{mmol})$ were purchased from Dupont-NEN (Boston, MA). T4 polynucleotide kinase, RNasin RNase inhibitor, RNase H, and SP6 RNA polymerase were obtained from Promega Corp. (Madison, WI). All human GLUT1 antisense oligonucleotides (ODNs) were purchased from Keystone

1. Abbreviations used in this paper: ARE, AU-rich element; AU, adenosine-uridine; AUBP, AU binding protein; GAPDH, glyceraldehyde 3-phosphate dehydrogenase; GBM, glioblastoma multiforme; GLUT1, glucose transporter 1; GSMA, gel-shift mobility assay; HB, hemangioblastoma; ODN, oligodeoxynucleotide; UTR, untranslated region; UV, ultraviolet light. 
Laboratory, Inc. (Menlo Park, CA). Prestained molecular weight protein standards and DNA-grade agarose were purchased from BioRad Laboratories (Richmond, CA). DE-81 and 3MM filters were purchased from Whatman International, Ltd. (Maidstone, UK). All other molecular biology-grade reagents were obtained from Sigma Chemical Co. (St. Louis, MO). Mouse mAb 40.10.09 (12) to human placental glyceraldehyde-3-phosphate dehydrogenase (GAPDH) was provided by Dr. Michael Sirover (Temple University School of Medicine, Philadelphia, PA).

Human brain tumor tissues were obtained from patients who underwent craniotomy for therapeutic reasons (Dr. Keith L. Black, UCLA Division of Neurosurgery, Los Angeles, CA). Immediately after resection, the tissues were placed in cryovials, deep-frozen in liquid $\mathrm{N}_{2}$ and kept at $-70^{\circ} \mathrm{C}$ before preparation of cytosolic fraction. The diagnosis of glioblastoma multiforme (GBM) or hemangioblastoma (HB) was confirmed by the UCLA Division of Neuropathology.

Preparation of tumor cytosolic fraction. All procedures were carried out at $0-4^{\circ} \mathrm{C}$. The tumor tissues were homogenized in 5 vol ice cold $10 \mathrm{mM}$ Hepes, $\mathrm{pH} 7.4,3 \mathrm{mM} \mathrm{MgCl} 2,40 \mathrm{mM} \mathrm{KCl}, 5 \%$ glycerol, $0.1 \mathrm{mM}$ DTT, $10 \mathrm{mM}$ leupeptin, and $5 \mu \mathrm{g} / \mathrm{ml}$ phenylmethyl-sulfonyl fluoride using a Dounce homogenizer (Konte Glass, Co., Vineland, NJ) (tight fitting, 10 strokes). The postmitochondrial supernatant $(14,000 \mathrm{~g}, 30 \mathrm{~min})$ was then centrifuged at $160,000 \mathrm{~g}$ for $40 \mathrm{~min}$ in an airfuge (Beckman Instruments, Inc., Fullerton, CA). The supernatant was concentrated with a Centricon-10 (Amicon Corp., Danvers, MA) and stored at $-70^{\circ} \mathrm{C}$ until used as a cytosolic fraction. Proteins were determined using the bicinchoninic acid protein assay reagent (Pierce, Rockford, IL) with bovine serum albumin as a standard. SDS-PAGE and Coomassie blue staining were performed on 100- $\mu$ g aliquots and $12 \%$ polyacrylamide slab gels $(120 \times 140 \times 1.5 \mathrm{~mm})$; the tumor cytosolic proteins covered a broad spectrum ranging from $12-200 \mathrm{kD}$.

Transcription plasmids. The human GLUT1 cDNA plasmids, pSPGT (13) and pGT25S (14), were kindly provided by Dr. Mike Mueckler (Washington University, St. Louis, MO). The pSPGT contains the hGLUT1 open reading frame and $3^{\prime}$-UTR and eight nucleotides of the hGLUT1 5'-UTR. To obtain full-length GLUT1 mRNA, the EcoRI fragment of pSPGT was replaced by the EcoRI fragment of pGT25S, to yield a new transcription plasmid, pSP-hGLUT1 containing the SP6 RNA polymerase promoter, as described previously (15). The pSP-hGLUT1 was prepared for the in vitro transcription of human GLUT1 RNA by digesting separately with restriction endonucleases XbaI, HindIII, or SspI for preparation of sense RNA with a $3^{\prime}$-UTR of varying length, and designated RNA ${ }^{\text {Xbal }}$, RNA ${ }^{\text {HindIII }}$, and RNA $^{\text {SspI }}$, respectively (Fig. 1). Linearization of the pSP-hGLUT1 plasmid with $\mathrm{XbaI}$ gave a single band of $5.7 \mathrm{~kb}$; linearization with HindIII gave two fragments of 5.1 and $0.6 \mathrm{~kb}$; and linearization with SspI gave three fragments of 2.7, 2.3, and $0.7 \mathrm{~kb}$, on agarose gel electrophoresis, respectively. The plasmid could not be digested with SpeI, indicating the poly A tail had been deleted (14). Proteinase K $(50 \mu \mathrm{g} / \mathrm{ml})$ was added to the linearized plasmids and incubated for 30 $\min$ at $37^{\circ} \mathrm{C}$. After phenol/chloroform extraction and ethanol precipitation, the plasmid pellet was resuspended in $10 \mathrm{mM}$ Tris, $\mathrm{pH} 8.0$, and $0.1 \mathrm{mM}$ EDTA to $1 \mu \mathrm{g} / \mu \mathrm{l}$.

The plasmid pT3/T7 $\alpha$-19-AUUUA was linearized with EcoRI and used as a template to transcribe an 80-base RNA transcript containing four consecutive AUUUA iterations of the adenosine-uridine-rich element (ARE) with T7 RNA polymerase (16). After linearization with EcoRI, the pT3/T $7 \alpha-19$-AUUUA plasmid migrated as a single $3.0 \mathrm{~kb}$ fragment on a $0.8 \%$ agarose gel. The synthetic RNA obtained with this transcription plasmid migrated at a mol wt of 8090 nucleotides on an $8 \%$ polyacrylamide/7 M urea gel.

In vitro transcription. The in vitro transcription reaction (17) was performed in a $25-\mu \mathrm{l}$ vol by the addition of the DNA template $(0.04$ $\mu \mathrm{g} / \mu \mathrm{l})$ to transcription buffer (40 mM Tris, $\mathrm{pH} 7.9,6 \mathrm{mM} \mathrm{MgCl}$, $2 \mathrm{mM}$ spermidine, and $10 \mathrm{mM} \mathrm{NaCl}$ ). Nucleotide triphosphates (UTP, GTP, CTP) were added to a final concentration of $0.4 \mathrm{mM}$ with the exception of ATP, which was present at a $40-\mu \mathrm{M}$ concentration when ${ }^{32} \mathrm{P}$-RNA was prepared. The in vitro transcription of unla- beled competitor RNA used all nucleotide triphosphates at a final concentration of $0.4 \mathrm{mM}$. After the addition of nucleotide triphosphates, DTT to $10 \mathrm{mM}$, and RNasin RNase inhibitor to $2 \mathrm{U} / \mu \mathrm{l}, 2 \mu \mathrm{Ci} /$ $\mu l$ of $\left[\alpha^{32} \mathrm{P}\right] \mathrm{ATP}(800 \mathrm{Ci} / \mathrm{mmol})$ was added to the transcription reactions. SP6 RNA polymerase $(2 \mathrm{U} / \mu \mathrm{l})$ was added and reactions were incubated for $60 \mathrm{~min}$ at $37^{\circ} \mathrm{C}$, after which RNase-free DNase I $(0.8 \mathrm{U} /$ $\mu \mathrm{l})$ was added and incubation continued for $15 \mathrm{~min}$ at $37^{\circ} \mathrm{C} .{ }^{32} \mathrm{P}-\mathrm{RNA}$ was phenol/chloroform extracted and column purified through a G-25 spin column (Boehringer Mannheim, Inc., Indianapolis, IN). The efficiency of the labeling reaction was determined by adsorption to DE-81 filters as reported previously (18). The purity of the ${ }^{32} \mathrm{P}$ RNA was determined after the G-25 purification step by adsorption to the DE- 81 filters. The specific activity of the ${ }^{32} \mathrm{P}-\mathrm{RNA}(\mu \mathrm{Ci} / \mathrm{pmol})$ was calculated from the final specific activity of $\left[\alpha^{32} \mathrm{P}\right] \mathrm{ATP}$ and the number of adenosine residues per molecule of the transcribed ${ }^{32} \mathrm{P}$ RNAs. Purity of ${ }^{32} \mathrm{P}-\mathrm{RNAs}$ was greater than $99 \%$ and specific activities of the ${ }^{32} \mathrm{P}-\mathrm{RNA}^{\mathrm{XbaI}},{ }^{32} \mathrm{P}-\mathrm{RNA}^{\text {HindIII }}$, and ${ }^{32} \mathrm{P}-\mathrm{RNA}^{\text {sspI }}$ were 25.7 , 18.9 , and $15.3 \mu \mathrm{Ci} / \mathrm{pmol}$, respectively. The length of the ${ }^{32} \mathrm{P}-\mathrm{RNA}$ was determined by electrophoresis in a $1.1 \%$ agarose $/ 2.2 \mathrm{M}$ formaldehyde denaturing gel using RNA sizing markers as molecular size standards. Labeled RNAs were stored at $-70^{\circ} \mathrm{C}$ and used within $72 \mathrm{~h}$ to minimize degradation.

Gel-shift mobility assay (GSMA) and UV cross-linking. GSMA and UV cross-linking experiments were adapted from Leibold and Munro (19), as described by Dwyer et al. (8). Tumor cytosolic proteins were added to $20 \mu \mathrm{l}$ of binding buffer (12 mM Hepes, $\mathrm{pH} 7.5,0.25 \mathrm{mM}$ EDTA, $10 \mathrm{mM} \mathrm{KCl}, 5 \mathrm{mM} \mathrm{MgCl} 2,0.5 \mathrm{mM}$ DTT, $0.2 \mu \mathrm{g} / \mu \mathrm{l}$ yeast tRNA, and 5\% glycerol). RNasin RNase inhibitor (20) was added to a concentration of $0.5 \mathrm{U} / \mu \mathrm{L}$ to inhibit endogenous RNase A. Unlabeled RNA competitors were added to the binding reactions at this point and incubated for $10 \mathrm{~min}$ at $22^{\circ} \mathrm{C} .{ }^{32} \mathrm{P}-\mathrm{RNA}\left(1 \times 10^{5} \mathrm{cpm} / \mu \mathrm{l}\right)$ was then added and incubated for $10 \mathrm{~min}$ at $30^{\circ} \mathrm{C}$. When antisense ODNs were used as competitors (21), the order of addition was altered as follows: ${ }^{32} \mathrm{P}-\mathrm{RNA}$ was preincubated with antisense ODNs for $2 \mathrm{~min}$ at $65^{\circ} \mathrm{C}$, followed by $10 \mathrm{~min}$ at $22^{\circ} \mathrm{C}$. Cytosolic proteins and RNasin were then added and incubated for $10 \mathrm{~min}$ at $30^{\circ} \mathrm{C}$. RNase $\mathrm{T} 1$ was then added to all reaction mixtures $(5 \mathrm{U} / \mu \mathrm{l})$ and incubated for $30 \mathrm{~min}$ at $37^{\circ} \mathrm{C}$. For GSMA, reactions were directly applied to a $100 \times 80 \times 1.5 \mathrm{~mm}$ $7 \%$ polyacrylamide native gel $(0.25 \times \mathrm{TBE}[0.0125 \mathrm{M}$ Tris, $0.0125 \mathrm{M}$ bo-

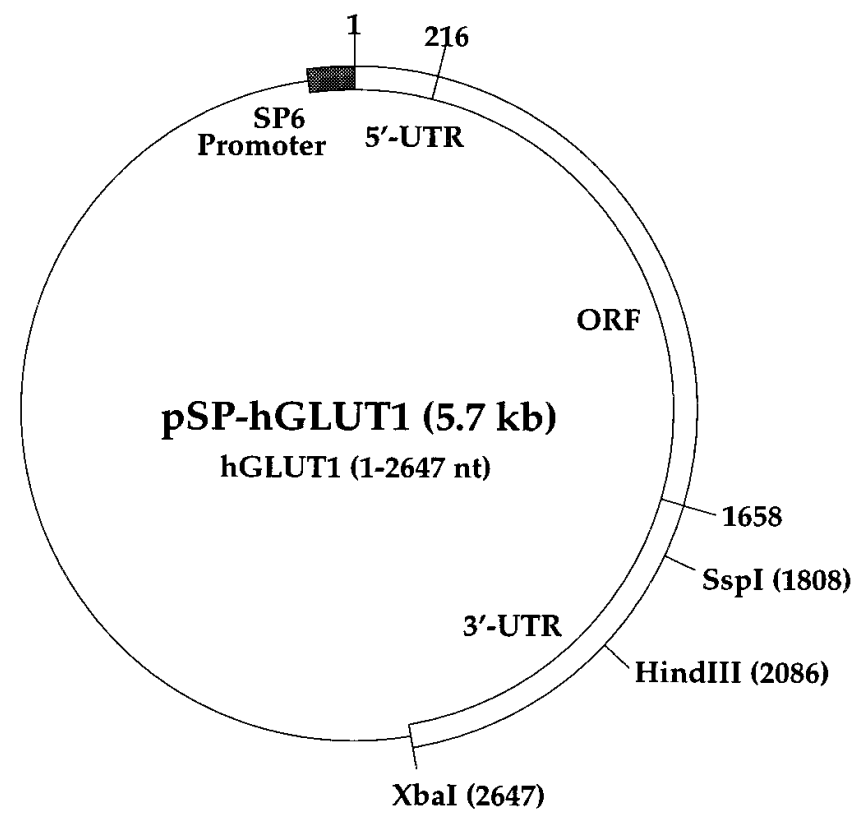

Figure 1. Transcription plasmid, pSP-hGLUT1, used to generate human GLUT1 mRNA with SP6 RNA polymerase after linearization with XbaI, HindIII, or SspI. 
ric acid, $0.25 \mathrm{mM}$ EDTA, $\mathrm{pH}=8.6]$ ) and electrophoresis was performed at $10 \mathrm{~V} / \mathrm{cm}$ until the xylene cyanol dye front migrated $8 \mathrm{~cm}$.

For UV cross-linking studies, after the RNase T1 digestion, reaction mixtures were irradiated in a UV oven (Stratalinker 1800; Stratagene Inc.) at $254 \mathrm{~nm}$ for 5 min on automatic setting. Binding reactions were then solubilized in SDS sample buffer with or without 2-mercaptoethanol (5\%) and boiled for $3 \mathrm{~min}$. RNA/protein complexes were then applied to a $12 \%$ SDS-PAGE gel $(80 \times 100 \times 1.0$ $\mathrm{mm}$ ) until the bromophenol blue dye front migrated $8 \mathrm{~cm}$.

After the electrophoresis, the gels were dried on 3MM filter paper with a slab gel dryer (No. 583, Bio Rad Laboratories, Inc.) and exposed at $-70^{\circ} \mathrm{C}$ to film using intensifying screens (X-OMAT; Eastman Kodak Co., Rochester, NY). Film autoradiograms were scanned with a (Scanjet IIcx/T; Hewlett-Packard Co., Palo Alto, CA), flatbed scanner imported into Adobe Photoshop, and quantified using National Institutes of Health Image 1.45 software on a Power Macintosh 7100/66 AV microcomputer. The relative OD ratio was computed from the OD of the autoradiograph signal in the absence of competitor RNA or ODN relative to the OD in the presence of competitor RNA or ODN.

Super-shift gel mobility assays (22) were performed by adding 1 $\mu \mathrm{g}$ of mAb 40.10 .09 to the GSMA mixture of $20 \mu \mathrm{g}$ GBM cytosolic protein and $10^{5} \mathrm{cpm}$ of ${ }^{32} \mathrm{P}-\mathrm{RNA}^{\text {HindIII }}$. After a 15 -min incubation at $30^{\circ} \mathrm{C}$, the RNase $\mathrm{T} 1$ was added and electrophoresis was performed as described above.

RNase T1 mapping. For RNase T1 mapping, the wet gels were left on the glass plate, wrapped in plastic, and frozen at $-70^{\circ} \mathrm{C}$. RNA/ protein complexes were eluted from frozen gel sections. RNase T1 mapping was adapted from Leibold and Munro (19) and Nickelsen and Link (23), as described by Dwyer et al. (8). Using a film autoradiograph as a template, RNA/protein complexes were eluted from gel sections in elution buffer $\left(0.5 \mathrm{M} \mathrm{NH}_{4}\right.$ acetate, $1 \mathrm{mM}$ EDTA, and 0.05 $\mathrm{U} / \mu \mathrm{l} \mathrm{RNasin})$ for $3 \mathrm{~h}$ at $22^{\circ} \mathrm{C}$, extracted with phenol/chloroform, and then ethanol precipitated with yeast tRNA $(15 \mu \mathrm{g} / \mathrm{ml})$ as carrier. The resulting pellet was dried in a vacuum centrifuge evaporator (Savant Instruments, Inc., Farmingdale, NY) and resuspended in digestion buffer (10 mM Tris, pH 7.4, $1 \mathrm{mM}$ EDTA). Eluted RNA fragments

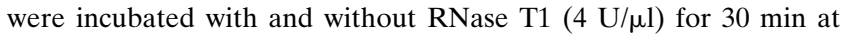
$37^{\circ} \mathrm{C}$. Stop solution was added to each reaction and samples were boiled for $2 \mathrm{~min}$. Reactions and ${ }^{32} \mathrm{P}$-labeled molecular size markers were applied to a $210 \times 500 \times 0.4 \mathrm{~mm} 20 \%$ polyacrylamide/7 M urea denaturing gel $(1 \times \mathrm{TBE})$ and electrophoresed at $40 \mathrm{~V} / \mathrm{cm}$ until the xylene cyanol dye front migrated $10 \mathrm{~cm}$. The gel was then fixed in $10 \%$ acetic acid $/ 5 \%$ methanol for $15 \mathrm{~min}$, washed with $\mathrm{dH}_{2} \mathrm{O}$ for 15 min, transferred to $3 \mathrm{MM}$ filter paper, dried, and exposed at $-70^{\circ} \mathrm{C}$.

Oligonucleotide sizing markers ( 8 to 32 nucleotides) were prepared by labeling oligonucleotides at the $5^{\prime}$ terminus with polynucleotide T4 kinase and $\left[\gamma^{32} \mathrm{P}\right]$ ATP $(3,000 \mathrm{Ci} / \mathrm{mmol})$ in $50 \mathrm{mM}$ Tris, $\mathrm{pH}$ $8.0,10 \mathrm{mM} \mathrm{MgCl} 2$, and $10 \mathrm{mM}$ DTT for $30 \mathrm{~min}$ at $37^{\circ} \mathrm{C}$. Loading buffer was added and the reaction mixture heated to $90^{\circ} \mathrm{C}$ for $3 \mathrm{~min}$ before application to the gel.

Cell-free GLUT1 mRNA stability assay. The differential susceptibility of ${ }^{32} \mathrm{P}-\mathrm{RNA}^{\mathrm{Xbal}}$ or ${ }^{32} \mathrm{P}-\mathrm{RNA}{ }^{\mathrm{SspI}}$ to tumor RNases in either GBM or HB cytosolic extracts was analyzed with an in vitro mRNA stability assay (24). A $0.08-\mu \mathrm{g}$ cytosolic protein aliquot was incubated with $100,000 \mathrm{cpm}$ of ${ }^{32} \mathrm{P}-\mathrm{RNA}$ in a final volume of $30 \mu \mathrm{l}$ at $37^{\circ} \mathrm{C}$ for 0 , 3,6 , or $12 \mathrm{~min}$. The assay buffer contained $0.01 \mathrm{M}$ TRIS, $\mathrm{pH} 7.4,0.1 \mathrm{M}$ potassium acetate, $5 \mathrm{~mm} \mathrm{MgCl}_{2}, 2 \mathrm{mM}$ DTT, and $200 \mu \mathrm{g} / \mathrm{ml}$ yeast transfer RNA, but no RNasin RNase inhibitor. The assay was performed with $0.02,0.08,0.2,4$, and $20 \mu \mathrm{g}$ cytosolic protein, and a protein concentration of $2.7 \mu \mathrm{g} / \mathrm{ml}$ was found to be optimal. The assay was terminated by the addition of phenol/chloroform. Aliquots were enriched with yeast transfer RNA and electrophoresed on $1.5 \%$ agarose/ 2.2 $\mathrm{M}$ formaldehyde gels, followed by film autoradiography and scanning densitometry. The data were expressed as a percentage of intact $2.7 \mathrm{~kb}^{32} \mathrm{P}-\mathrm{RNA}^{\mathrm{Xbal}}$ or $1.8 \mathrm{~kb}^{32} \mathrm{P}-\mathrm{RNA}{ }^{\mathrm{SspI}}$ remaining at each incubation time. Assays were performed in triplicate and the intraassay coefficient of variation was $10.3 \pm 3.2 \%$ (average of seven sets of trip- licates). Control experiments showed that $5^{\prime}$-capping or a $3^{\prime}$-poly A tail did not influence the rate of GLUT1 mRNA degradation. 5 -capped mRNA was prepared by replacing $20 \%$ of the GTP in the in vitro transcription with $0.16 \mathrm{mM}$ cap analogue, $7^{\mathrm{m}} \mathrm{G}\left(5^{\prime}\right) \mathrm{ppp}\left(5^{\prime}\right) \mathrm{G}$ (New England Biolabs Inc.) (15). The effect of a poly A tail was analyzed by in vitro transcription with T7 RNA polymerase of ClaI-linearized pBS746. This transcription plasmid was prepared by subcloning the full length rat GLUT1 glucose transporter cDNA (25), which included a 28-mer poly A tail, into the pBluescript transcription plasmid (Stratagene Inc.). The orientation of this plasmid was confirmed by restriction endonuclease digestion, and the presence of the poly $\mathrm{A}$ tail was demonstrated by dideoxy DNA sequencing. In vitro transcription of the ClaI-linearized plasmid yielded a single mRNA species of $2.6 \mathrm{~kb}$.

Western blotting. GBM or HB cytosolic proteins $(20 \mu \mathrm{g})$ were electrophoresed through $12 \%$ SDS-PAGE under reducing conditions. After electro-blotting to a nylon membrane (Gene Screen Plus; Dupont-NEN), the filter was probed with $1-10 \mu \mathrm{g} / \mathrm{ml}$ of $\mathrm{mAb}$ 40.10.09 or the mouse IgG1 isotype control. The gels were scanned and quantified as described above.

\section{Results}

GSMA binding reactions using a constant mass of ${ }^{32} \mathrm{P}-\mathrm{RNA}^{\mathrm{Xba}}$ ( 1.6 ng) and 0 to $20 \mu \mathrm{g}$ of human brain tumor cytosolic proteins are shown in Fig. 2. The addition of GBM proteins to ${ }^{32} \mathrm{P}-\mathrm{RNA}^{\mathrm{XbaI}}$ resulted in the formation of at least three RNA/ protein complexes (A, B, and $\mathrm{C}$ ) that were resolved in $7 \%$ native polyacrylamide gels (Fig. 2, lanes 3-6). In contrast, one major RNA/protein complex (complex B) with some minor complexes was resolved when the HB cytosolic fraction was used as a protein source (Fig. $2 A$, lanes 7-10). Scanning densitometry of RNA/protein complexes showed the formation of four major ${ }^{32} \mathrm{P}-\mathrm{RNA}{ }^{\mathrm{XbaI}} /$ protein complexes reached near saturation at $20 \mu \mathrm{g}$ of tumor cytosolic proteins (Fig. $2 \mathrm{~B}$ ); therefore, this protein mass $(20 \mu \mathrm{g})$ was used in subsequent experiments.

${ }^{32} \mathrm{P}-\mathrm{RNA}^{\mathrm{Xba} /} /$ tumor protein complexes formed in binding reactions were covalently cross-linked using UV and further analyzed with $12 \%$ SDS-PAGE to determine the molecular mass of complexes (Fig. 3). RNA/protein complexes of 120, 44, and $41 \mathrm{kD}$ were identified by the addition of GBM proteins to the binding reactions (Fig. $3 A$, lanes $3-5$ ). The addition of $\mathrm{HB}$ proteins resulted in the formation of the 120-kD RNA/protein complex and minor 41-kD complexes (Fig. $3 B$ ); however, no 44-kD complex (Fig. $3 A$, lanes $6-8$ ). Therefore, GBM protein was mainly used in subsequent experiments to identify the ciselement of human GLUT1 mRNA involved in formation of major 120- and 44-kD RNA/protein complexes. Radioactive bands below $20 \mathrm{kD}$ (Fig. $3 A$ ) are the unbound ${ }^{32}$ P-RNA fragments because they were also observed in lane 2 of Fig. $3 A$, where no tumor proteins were added. The addition of 2-mercaptoethanol to the SDS sample buffer caused no shift in mobility of these RNA/protein complexes (data not shown), suggesting that neither protein is found in a complex involving disulfide bonds. No complex was formed when the ${ }^{32} \mathrm{P}-\mathrm{RNA}^{\mathrm{XbaI}}$ was incubated with human serum albumin $(10 \mu \mathrm{g})$, human hemoglobin $(10 \mu \mathrm{g})$, calf thymus histone II $(10 \mu \mathrm{g})$, or histone III-S $(10 \mu \mathrm{g})$, suggesting that interaction between ${ }^{32} \mathrm{P}-\mathrm{RNA}^{\mathrm{XbaI}}$ and tumor proteins participating in the complex formation is specific. No GBM- or HB- complex formation was observed in the absence of UV irradiation of the sample.

The specificity of RNA/protein complex formation was fur- 
A

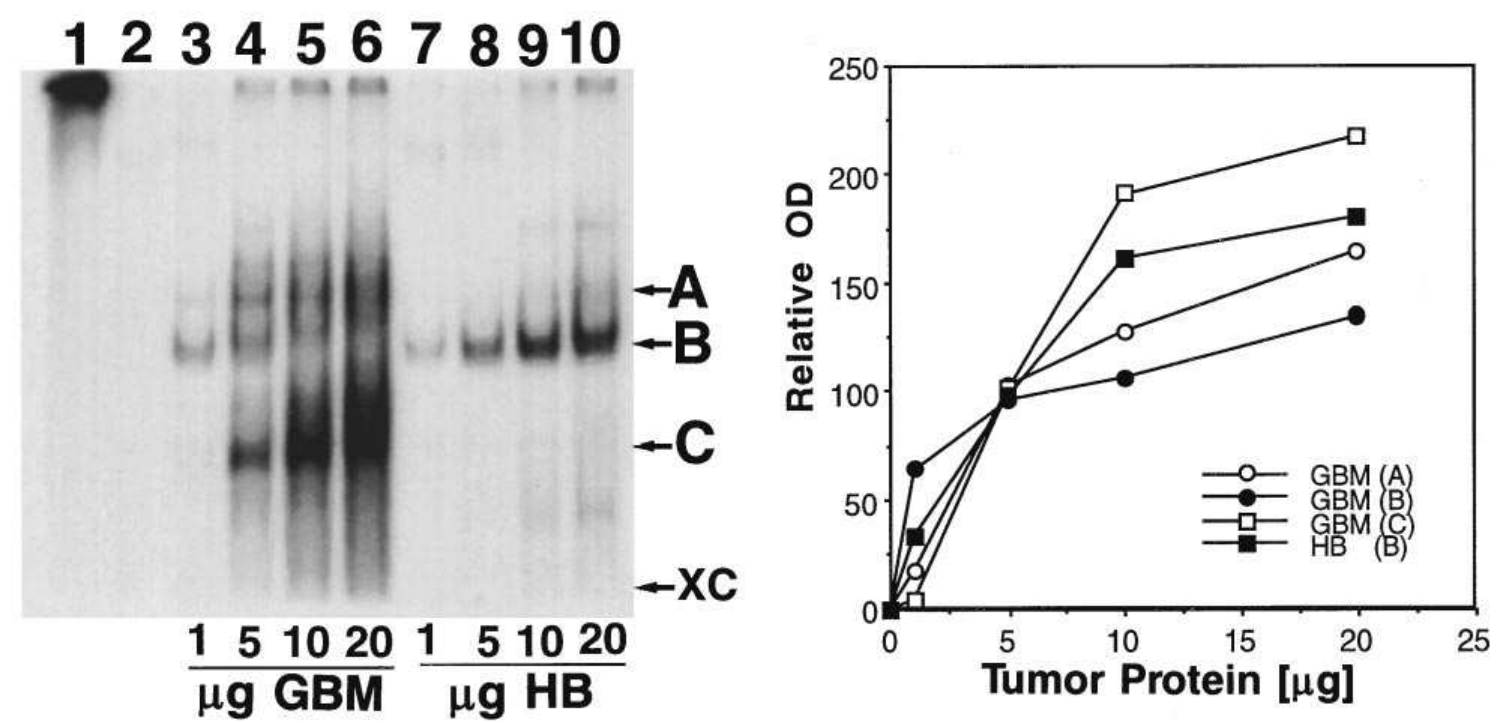

Figure 2. GSMA of ${ }^{32} \mathrm{P}-\mathrm{RNA}^{\mathrm{XbaI}}$ with increasing amounts of human brain tumor cytosolic proteins. $(A)$ Increasing amounts of human brain tumor cytosolic proteins were added to ${ }^{32} \mathrm{P}-\mathrm{RNA}^{\mathrm{XbaI}}\left(10^{5} \mathrm{cpm}\right)$ in binding reactions where RNA/protein complexes were incubated at $30^{\circ} \mathrm{C}$ followed by digestion with RNase T1. The RNA/protein complex formation was applied to $7 \%$ polyacrylamide native gels $(0.25 \times \mathrm{TBE})$ and complex formation was characterized by film autoradiography. Autoradiogram was exposed for $72 \mathrm{~h}$ at $-70^{\circ} \mathrm{C}$. The migration of RNA/protein complexes $\mathrm{A}, \mathrm{B}$, and $\mathrm{C}$, and xylene cyanol $(X C)$ are indicated at the right margin. Lane $1,{ }^{32} \mathrm{P}-\mathrm{RNA}^{\mathrm{Xbal}}$ alone; lane $2,{ }^{32} \mathrm{P}-\mathrm{RNA}{ }^{\mathrm{Xbal}}$ plus RNase T1; lanes 3-6, ${ }^{32} \mathrm{P}-\mathrm{RNA}^{\mathrm{Xbal}}$ plus RNase T1 plus GBM proteins (1-20 $\mu \mathrm{g}$ protein); lanes $7-10,{ }^{32} \mathrm{P}-\mathrm{RNA}{ }^{\mathrm{Xbal}}$ plus RNase T1 plus HB proteins (1-20 $\mu \mathrm{g}$ protein). (B) Formation of RNA/protein complexes A, B, and C in GBM, and B in HB was quantitated with scanning densitometry and the relative OD units were plotted against the mass of brain tumor cytosolic proteins.

ther determined by the addition of unlabeled competitor RNA to the binding reactions of ${ }^{32} \mathrm{P}-\mathrm{RNA}{ }^{\mathrm{Xba}}$ and GBM proteins (Fig. 4). The unlabeled sense human GLUT1 mRNA was generated by linearization of pSP-hGLUT1 with XbaI and transcription with SP6 RNA polymerase. The formation of the three RNA/protein complexes was inhibited in a dose-dependent manner by the addition of unlabeled competitor RNA and almost completely inhibited by a 3,000-fold molar excess (Fig. 4).

RNase T1 mapping of the RNA sequence interacting with GBM proteins in RNA/protein complexes is shown in Fig. 5. The predominant RNA fragment eluted from the gel slices of complexes A and B (Fig. 2) was 52 bases in length. The 52-base fragment was still the predominant RNA fragment

A

B
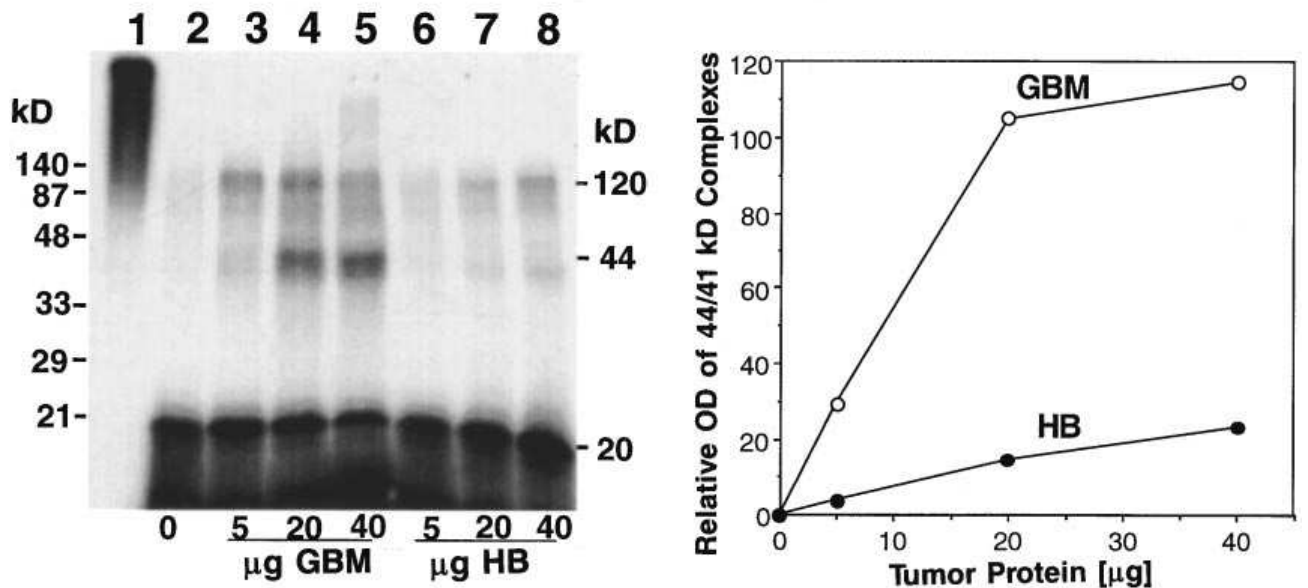

Figure 3. UV cross-linking of ${ }^{32} \mathrm{P}-\mathrm{RNA}^{\mathrm{Xba}} / \mathrm{brain}$ tumor protein complexes. ${ }^{32} \mathrm{P}-\mathrm{RNA} \mathrm{XbaI}^{\mathrm{Xb}}\left(10^{5} \mathrm{cpm}\right)$ were reacted with brain tumor proteins as described in Fig. 1. After RNase T1 digestion, RNA/protein complexes were covalently cross-linked using UV, and then resolved in a $12 \%$ SDSPAGE. Autoradiogram was exposed for $72 \mathrm{~h}$ at $-70^{\circ} \mathrm{C}$. RNA/protein complexes are indicated at right. Lane $1,{ }^{32} \mathrm{P}-\mathrm{RNA}{ }^{\mathrm{XbaI}}$ alone; lane $2,{ }^{32} \mathrm{P}-$ RNA $^{\text {Xbal }}$ plus RNase T1; lanes 3-8, ${ }^{32} \mathrm{P}-\mathrm{RNA}^{\mathrm{Xbal}}$ plus RNase T1 plus GBM (lanes 3-5) or HB (lanes 6-8) cytosolic protein (5-40 $\mu \mathrm{g}$ protein). Molecular size standards are indicated at left. 

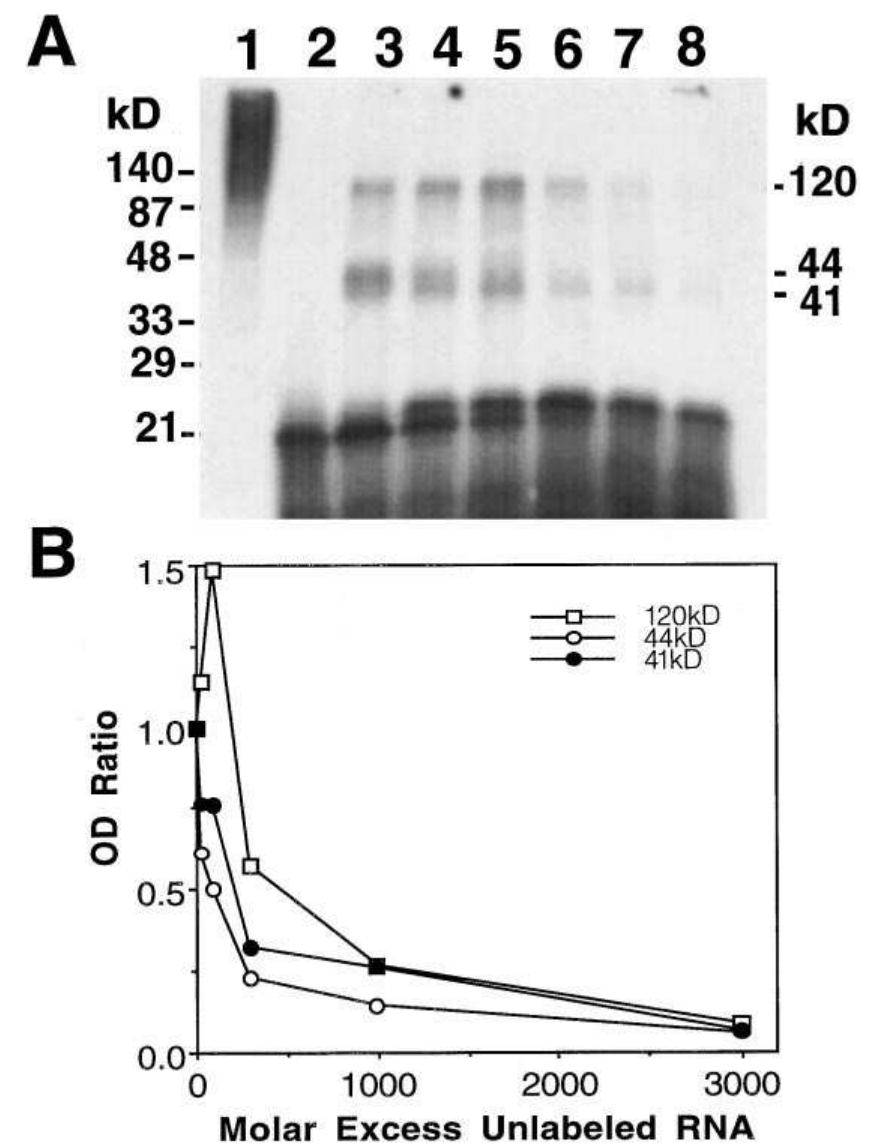

Figure 4. UV cross-linking of ${ }^{32} \mathrm{P}-\mathrm{RNA}^{\mathrm{Xba}} / \mathrm{GBM}$ protein complexes formed in the presence of competitor unlabeled RNA ${ }^{\mathrm{Xba}}$. (A) After RNase T1 digestion followed by UV cross-linking, RNA/protein complexes were resolved in a $12 \%$ SDS-PAGE. Autoradiogram was performed at $-70^{\circ} \mathrm{C}$ for $72 \mathrm{~h}$. Lane $1,{ }^{32} \mathrm{P}-\mathrm{RNA}^{\mathrm{Xbal}}$ alone; lane 2 , ${ }^{32} \mathrm{P}-\mathrm{RNA}^{\mathrm{Xbal}}$ plus RNase T1; lanes $3-8,{ }^{32} \mathrm{P}-\mathrm{RNA}^{\mathrm{Xbal}}$ and GBM proteins without (lane 3) and with 30- (lane 4), 100- (lane 5), 300- (lane 6), 1,000- (lane 7), and 3,000-fold (lane 8 ) molar excess of competitor unlabeled RNA ${ }^{\mathrm{Xba}}$, and digested with RNase T1. Molecular size standards are indicated at left. (B) Formation of RNA/protein complexes were quantitated, and the relative OD ratio (OD binding reaction with competitor/OD binding reaction without competitor) was plotted against the molar excess of competitor unlabeled RNA ${ }^{\text {XbaI }}$.

even if the gel-eluted RNA fragment was redigested with RNase T1 (Fig. 5, lanes 4 and 6). The predominant RNA fragment eluted from the gel slice of RNA/HB protein complex B (Fig. 2) was also 52 bases in length even after RNase T1 redigestion (data not shown). These data suggest that one of the cis-elements responsible for complex formation is encompassed within a 52-base RNase T1-resistant fragment within the human GLUT1 mRNA. Only one 52-base sequence lacking $\mathrm{G}$ residues is present within the human GLUT1 mRNA sequence (14), and corresponds to nucleotides 2173 to 2224 (Fig. $6 \mathrm{~A}$ ).

The localization of the cis-element to a region within the 52-base RNA fragment was confirmed with four overlapping ODNs antisense to the RNA fragment (Fig. $6 A$ ). The ODNs are designated $68,69,70$, and 71 and were added to binding reactions, and the effect of the ODNs on complex formation was determined by autoradiography (Fig. 6 B). The $120-\mathrm{kD}$ complex formation was specifically inhibited by addition of the

\section{6}

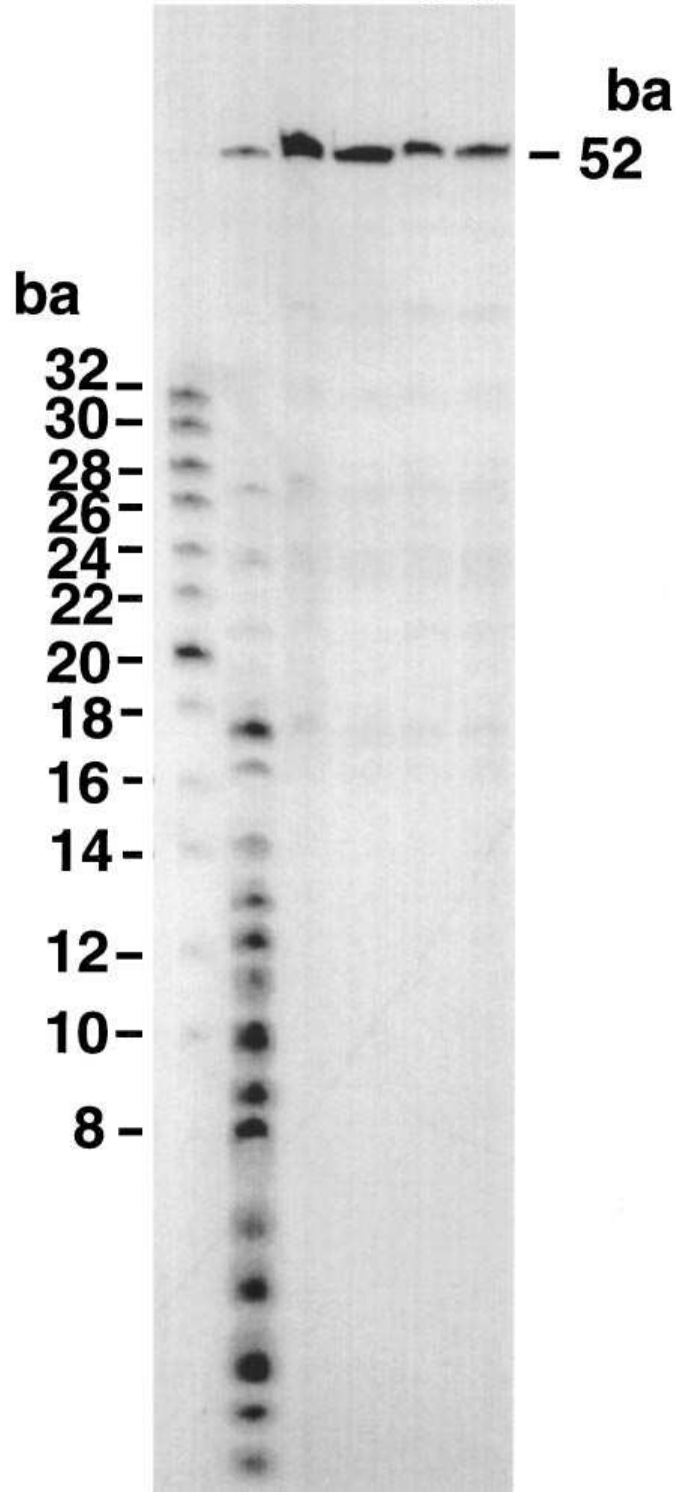

Figure 5. RNase T1 mapping of the human GLUT1 mRNA cis-element protected by binding of human GBM proteins. The protected transcripts generated from ${ }^{32} \mathrm{P}-\mathrm{RNA}{ }^{\mathrm{Xbal}}$ were isolated from RNA/ protein complexes A and B after GSMA (Fig. 1). The protected transcript was redigested with RNase T1 and resolved in $7 \mathrm{M}$ urea/20\% polyacrylamide gel. Autoradiogram was performed at $-70^{\circ} \mathrm{C}$ for $5 \mathrm{~d}$. Oligonucleotide size markers are indicated as number of bases $(b a)$ at left. Lane 1, size markers; lane 2, complete RNase T1 digestion of ${ }^{32} \mathrm{P}-\mathrm{RNA}^{\mathrm{Xbal}}$ without GBM protein protection; lanes 3 and 4 , protected transcript eluted from the RNA/protein complex A without (lane 3) or with (lane 4) RNase T1 redigestion; lanes 5 and 6, protected transcript eluted from the RNA/protein complex B without (lane 5) or with (lane 6) RNase T1 redigestion.

ODNs to the binding reactions, while the 44- and 41-kD bands were not affected by the ODNs. ODN 69 inhibited the $120-\mathrm{kD}$ complex formation to the greatest degree (Fig. $6 \mathrm{C}$ ). The highest level of inhibition of $120-\mathrm{kD}$ complex formation resulted from the addition of only 30-fold molar excess of ODN 69 to binding reactions, suggesting that the cis-element is contained within ODN 69. The 120-kD RNA/HB protein complex for- 


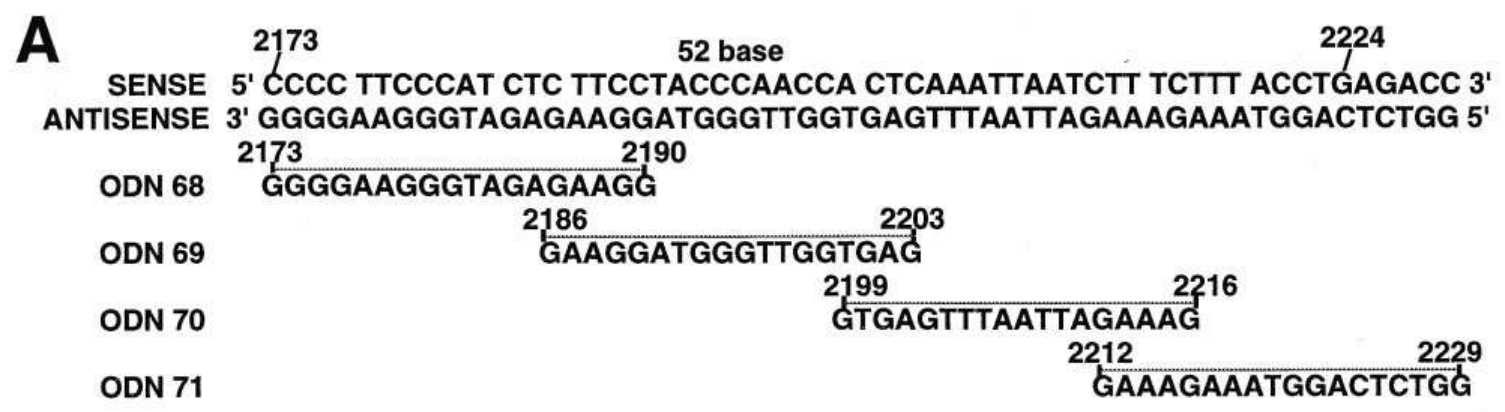

B

$\frac{\text { ODN } 68}{2345} \frac{\text { ODN } 69}{2345} 1 \frac{\text { ODN } 70}{2345} \frac{\text { ODN } 71}{2345}$
$1 \longdiv { 2 3 4 5 2 3 4 5 }$
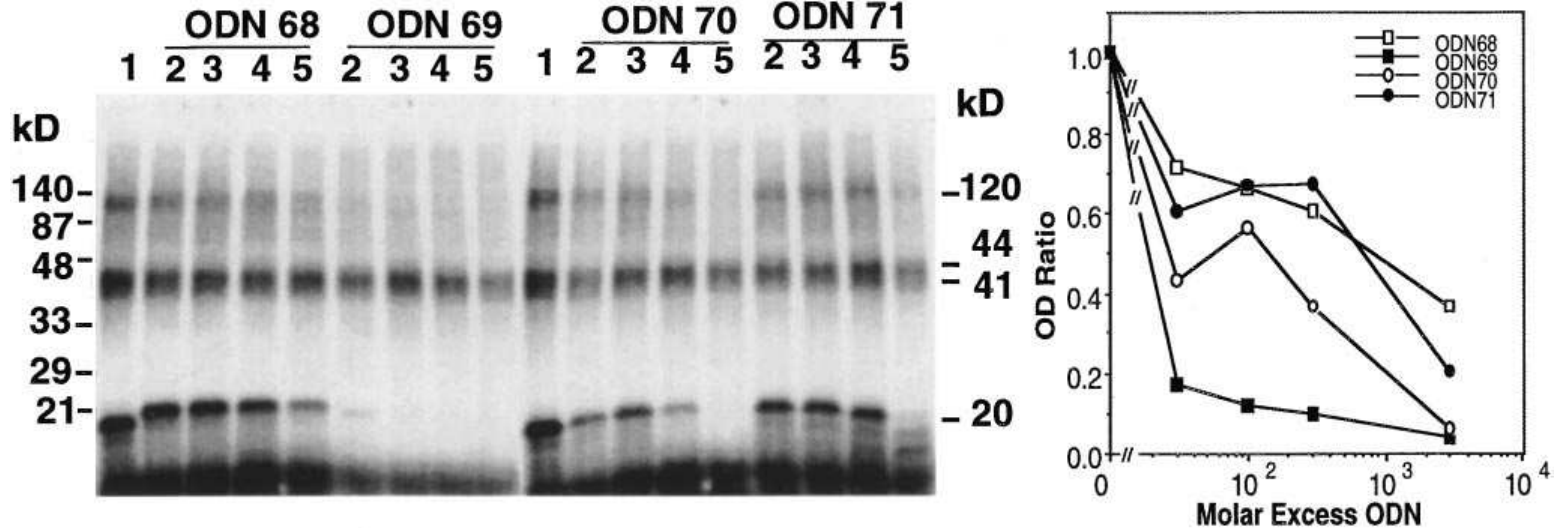

Figure 6. Localization of $3^{\prime}$-UTR cis-element to an 18-base sequence by antisense oligodeoxynucleotide competition. $(A)$ Sequence ( $5^{\prime}$ to $\left.3^{\prime}\right)$ of 52-base protected transcript of RNA/protein complex with the complementary antisense sequence $\left(3^{\prime}\right.$ to $\left.5^{\prime}\right)$. Four overlapping 18 -base oligodeoxynucleotides (ODNs 68-71) were prepared for use as competitors in binding reactions. (B) UV cross-linking of ${ }^{32} \mathrm{P}-\mathrm{RNA}^{\mathrm{Xbal}} / \mathrm{GBM}^{\mathrm{P}}$ protein complexes formed in the presence of antisense ODNs. Binding reactions of ${ }^{32} \mathrm{P}_{-\mathrm{RNA}}{ }^{\mathrm{XbaI}}\left(10^{5} \mathrm{cpm}\right)$ and $20 \mu \mathrm{g}$ of GBM proteins were performed with the antisense ODNs. RNA/protein complexes were resolved in a 12\% SDS-PAGE following T1 digestion and UV cross-linking. Autoradiogram was performed at $-70^{\circ} \mathrm{C}$ for $72 \mathrm{~h}$. The lanes corresponding to reactions containing the respective inhibitor are grouped according to ODN 68, ODN 69, ODN 70, or ODN 71. Lane 1, no competitor; lane 2, 30-fold molar excess; lane 3, 100-fold molar excess; lane 4, 300-fold molar excess; lane 5,3,000-fold molar excess. Molecular size standards are indicated at left. $(C)$ Formation of 120-kD RNA/protein complex was quantitated with scanning densitometry. The relative OD ratio was plotted against the molar excess of antisense competitors.

mation was also inhibited by the addition of the ODNs to binding reactions, and most strongly by ODN 69 (data not shown). The RNase T1 mapping and UV cross-linking studies using ODNs 68-71 as inhibitors of complex formation demonstrate that the putative cis-element involved in the $120-\mathrm{kD}$ complex is present in the human GLUT1 mRNA near nucleotides 2186 to 2203 (Fig. $6 \mathrm{~A}$ ). In addition to these data, considering GSMA (Fig. 2), the 120-kD RNA/protein complex in the UV cross-linking studies is considered to correspond to complex B and A in GSMA.

The formation of the $20-\mathrm{kD}$ band was also inhibited by addition of the ODNs to the binding reactions of ${ }^{32} \mathrm{P}-\mathrm{RNA}^{\mathrm{XbaI}}$ and GBM proteins (Fig. $6 \mathrm{~B}$ ). The RNA fragment eluted from this $20-\mathrm{kD}$ band was 52 bases in length regardless of proteinase $\mathrm{K}$ and RNase $\mathrm{T} 1$ redigestion of the eluant (data not shown), suggesting that the $20-\mathrm{kD}$ band is not a small RNA/protein complex, but the unbound 52-base fragment lacking $\mathrm{G}$ residues. The inhibition of the $20-\mathrm{kD}$ band formation by addition of the ODNs might result from digestion of the RNA/ODN duplex by RNase $\mathrm{H}$ in the GBM extract, because formation of the $20-\mathrm{kD}$ band was also inhibited by the addition of ODN 69 and exogenous RNase $\mathrm{H}$ to the reactions instead of GBM proteins (data not shown). However, the inhibition of the $120-\mathrm{kD}$ RNA/GBM protein complex formation by addition of the ODNs does not result from degradation of the $20-\mathrm{kD}$ band by the RNase H-like activity, because the inhibition of $120-\mathrm{kD}$ RNA/HB protein complex formation by the addition of the ODNs was not accompanied by inhibition of the $20-\mathrm{kD}$ band (data not shown).

The cis-elements within the GLUT1 3'-UTR were mapped by performing GSMA or UV cross-linking with GLUT1 mRNAs with progressive deletions of the 3'-UTR, and designated ${ }^{32} \mathrm{P}-\mathrm{RNA}^{\mathrm{XbaI}}$, ${ }^{32} \mathrm{P}-\mathrm{RNA}^{\text {HindIII }}$, and ${ }^{32} \mathrm{P}-\mathrm{RNA}^{\text {SspI }}$. The XbaI, HindIII, and SspI are predicted to yield GLUT1 mRNAs of 2,647, 2,086, and 1,808 nucleotides in length, respectively (Fig. 1). This was confirmed by $1.1 \%$ agarose $/ 2.2 \mathrm{M}$ formaldehyde gel electrophoresis (Fig. $7 A$ ). UV cross-linking of RNA/protein complexes formed between the three ${ }^{32} \mathrm{P}-\mathrm{RNAs}$ and GBM cytosolic proteins are shown in Fig. $7 \mathrm{~B}$. The addition of ${ }^{32} \mathrm{P}-\mathrm{RNA}^{\text {HindIII }}$ to the binding reactions resulted in the formation of only the 44-kD RNA/protein complex (Fig. $7 B$, lane 4 ), while this complex was not formed with the ${ }^{32} \mathrm{P}-\mathrm{RNA}^{\mathrm{SspI}}$ (Fig. $7 \mathrm{~B}$, lane 5), suggesting that the $44-\mathrm{kD}$ $\mathrm{RNA} /$ protein complex is mediated by binding of a GBM protein to a cis-element present between nucleotides 1808 and 2085 of the human GLUT1 3'-UTR (Fig. 1). The GSMA binding reactions between ${ }^{32} \mathrm{P}-\mathrm{RNA}^{\mathrm{HindIII}}$ and $\mathrm{GBM}$ proteins resulted in only complex $\mathrm{C}$ formation (data not shown), indicating the 44-kD RNA/protein complex in the UV cross-linking studies corresponds to complex $\mathrm{C}$ in the GSMA (Fig. $2 A$ ). 
A

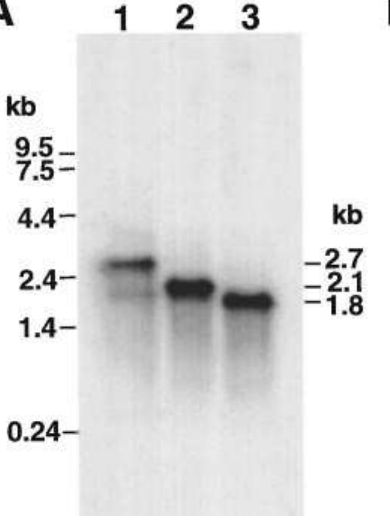

B

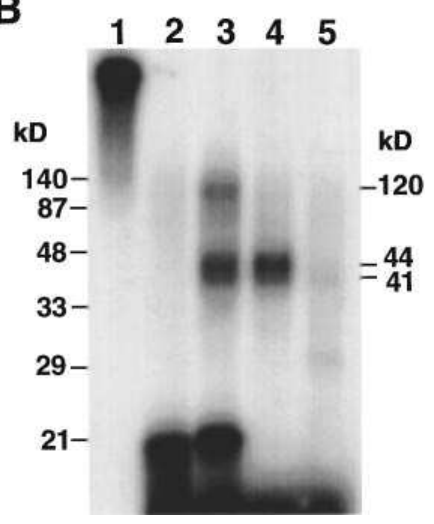

Figure 7. (A) In vitro transcription of ${ }^{32} \mathrm{P}$-labeled human GLUT1 mRNAs with different length of $3^{\prime}$-UTR. ${ }^{32} \mathrm{P}$-sense RNAs were transcribed by SP6 RNA polymerase after linearization of plasmid pSP-hGLUT1 with XbaI (lane 1), HindIII (lane 2), or SspI (lane 3). ${ }^{32} \mathrm{P}$-RNA transcripts $\left(5 \times 10^{3} \mathrm{cpm}\right)$ were resolved in $1.1 \%$ agarose $/ 2.2$ $\mathrm{M}$ formaldehyde gels. After drying the gel, the autoradiogram was exposed at $22^{\circ} \mathrm{C}$ for $16 \mathrm{~h}$. The sizes of the transcripts, indicated at right, were estimated by RNA molecular weight size ladder, indicated at left, detected by ethidium bromide staining. (B) UV cross-linking of RNA/protein complexes formed by using the three ${ }^{32} \mathrm{P}$-labeled human GLUT1 mRNAs with different length of $3^{\prime}$-UTRs. ${ }^{32} \mathrm{P}$-RNAs $\left(10^{5} \mathrm{cpm}\right)$ were reacted with $20 \mu \mathrm{g}$ of GBM proteins. After RNase T1 digestion followed by UV cross-linking, RNA/protein complexes were resolved in a $12 \%$ SDS-PAGE. Autoradiogram was performed for $72 \mathrm{~h}$ at $-70^{\circ} \mathrm{C}$. The molecular sizes of RNA/protein complexes are indicated at right. Lane $1,{ }^{32} \mathrm{P}-\mathrm{RNA}^{\mathrm{XbaI}}$ alone; lane $2,{ }^{32} \mathrm{P}-\mathrm{RNA}^{\mathrm{XbaI}}$ plus RNase T1; lanes 3-5, ${ }^{32} \mathrm{P}-\mathrm{RNA}^{\mathrm{XbaI}}$ (lane 3), ${ }^{32} \mathrm{P}-\mathrm{RNA}^{\text {HindIII }}$ (lane 4 ), and ${ }^{32} \mathrm{P}-\mathrm{RNA}{ }^{\text {SspI }}$ (lane 5) plus GBM proteins and digested with RNase T1. Molecular size standards are indicated at left.

RNase T1 mapping of the single complex formed between GBM proteins and ${ }^{32} \mathrm{P}-\mathrm{RNA}^{\text {HindIII }}$ in the GSMA is shown in Fig. 8. This RNA fragment consisted of a series of oligoribonucleotides ranging from 10-22 nucleotides in length. This "ladder" pattern was not changed after RNase T1 redigestion of the gel-eluted RNA fragment (Fig. 8, lane 4). The same ladder pattern was observed with RNase T1 mapping of complex C formed between GBM proteins and ${ }^{32} \mathrm{P}-\mathrm{RNA}^{\mathrm{Xbal}}$ (Fig. 2) (data not shown). The experiment in Fig. $7 B$ indicates the cis-element forming the 44-kD complex lies between the HindIII and SspI restriction sites at nucleotides 1808-2085 (Fig. 1). Within this region of human GLUT1 3'-UTR, the longest G-less sequence is a 22-mer corresponding to nucleotides 1885-1906 (Fig. 9); the next longest G-less sequence is a 15-base sequence corresponding to nucleotides 1913-1927 (Fig. 9 A), and a 15-mer corresponding to nucleotides 1858-1872 (13). Since the longest principal fragment is mapped at 22 nucleotides (Fig. 8), the ciselement responsible for formation of the complex $\mathrm{C}$ in the GSMA and the 44-kD complex in the UV cross-linking is predicted to be contiguous with nucleotides 1885-1906.

An ODN antisense to nucleotides 1874-1908 of human GLUT1 mRNA inhibited the 44-kD complex formation only at 3,000-fold molar excess (data not shown). However, the complex formation was inhibited by the addition of competitor-unlabeled sense RNA containing four consecutive AUUUA reiterations of the ARE at a concentration as low as a 30-fold molar excess, and completely by a 300 -fold molar excess, while the $120-\mathrm{kD}$ complex was not affected (Fig. 9, $B$ and $C$ ). Be-

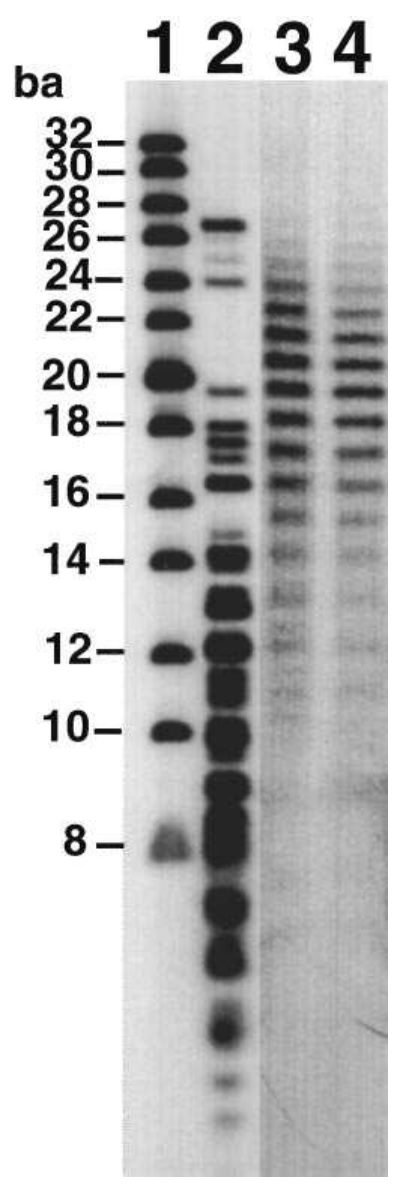

Figure 8. RNase T1 mapping of ${ }^{32} \mathrm{P}-\mathrm{RNA}^{\text {HindIII }}$ cis-element protected by binding of GBM proteins. GSMA using ${ }^{32} \mathrm{P}-\mathrm{RNA}^{\text {HindIII }}$ $\left(10^{5} \mathrm{cpm}\right)$ and $20 \mu \mathrm{g}$ of GBM proteins yielded a single complex that migrated identically to complex $C$ in Fig. 1. The protected ${ }^{32} \mathrm{P}-\mathrm{RNA}^{\text {HindIII }}$ fragment was eluted from the gel and resolved in $7 \mathrm{M}$ urea/20\% polyacrylamide gel. $\mathrm{Au}-$ toradiogram was exposed at $-70^{\circ} \mathrm{C}$ for $5 \mathrm{~d}$. Oligonucleotide size markers are indicated as number of bases $(b a)$ at left. Lane 1, size markers; lane 2, complete RNase $\mathrm{T} 1$ digestion of ${ }^{32} \mathrm{P}-\mathrm{RNA}^{\text {HindIII }}$ without GBM protein protection; lanes 3 and 4 , protected transcript eluted from the RNA/protein complex $\mathrm{C}$ without (lane 5) or with (lane 6) RNase T1 redigestion. The largest G-less fragments in the ${ }^{32} \mathrm{P}-\mathrm{RNA}^{\mathrm{HindIII}}$ are predicted to be 25 and 22 nucleotides in length (14), and the migration of these fragments (lane 2) is equivalent to the migration of 27- and 24-ba ODN standards (lane 1).

tween nucleotides 1808 and 2085 of human GLUT1 3'-UTR, the ARE is present only near nucleotides $1885-1906$, although no exact AUUUA sequence is found in this adenosine-uridine (AU)-rich region (Fig. $9 A$ ).

The differential susceptibility of ${ }^{32} \mathrm{P}-\mathrm{RNA}^{\mathrm{Xbal}}$ or ${ }^{32} \mathrm{P}-\mathrm{RNA}{ }^{\text {SspI }}$ to RNases in GBM or HB cytosolic extracts is shown in Fig. 10. In the absence of RNasin, the ${ }^{32} \mathrm{P}-\mathrm{RNA}^{\mathrm{XbaI}}$ was rapidly degraded $\left(t_{1 / 2}=3.5 \mathrm{~min}\right)$ by GBM cytosol, but was undegraded in the presence of HB cystol (Figure 10, $A$ and $B$ ). Conversely, the ${ }^{32} \mathrm{P}-\mathrm{RNA}^{\mathrm{SspI}}$ which is lacking in the putative endonuclease target site at nucleotides 1885-1906, is stable in the presence of GBM cytosol (Fig. 10, $C$ and $D$ ).

The cytosolic protein comprising the $44-\mathrm{kD}$ complex is of comparable size to GAPDH, a cytosolic enyzme that also binds to AU-rich regions of the $3^{\prime}$-UTR of cellular mRNAs (26). An anti-GAPDH mAb, 40.10 .09 (12), was used in Western blot analysis to show this enyzme was expressed in both GBM and HB, with a twofold abundance in the GBM compared to the HB proteins. The $40.10 .09 \mathrm{mAb}$ yielded no super shift in the GSMA that was performed as shown in Fig. $2 \mathrm{~A}$ with ${ }^{32} \mathrm{P}-\mathrm{RNA}^{\text {HindIII }}$ (see Methods).

\section{Discussion}

The findings of the present study are consistent with the following conclusions. First, human brain tumors contain cytosolic proteins that specifically bind to at least two different sites on the human GLUT1 mRNA and form RNA/protein com- 


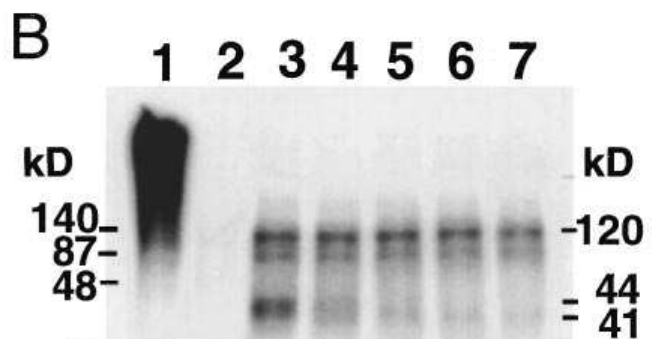

3329-

21-

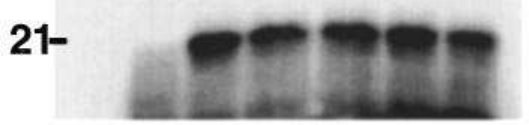

C

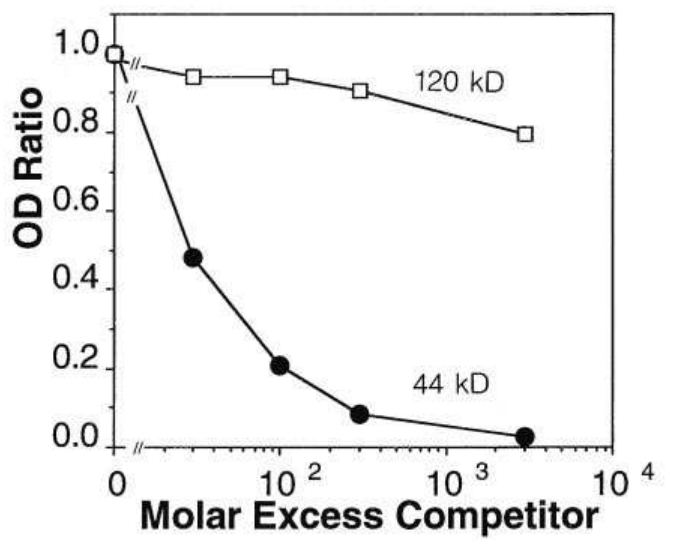
the presence of competitor RNA containing four consecutive AUUUA reiterations of ARE. (A) Partial RNA sequence corresponding to nucleotides 1880 and 1930 of the fulllength cDNA sequence of human GLUT1. (B) Binding reactions of ${ }^{32} \mathrm{P}-\mathrm{RNA}^{\mathrm{Xba}}$ $\left(10^{5} \mathrm{cpm}\right)$ and $20 \mu \mathrm{g}$ of GBM proteins were performed with the competitor RNA, and RNA/protein complexes were resolved in a $12 \%$ SDS-PAGE following RNase $\mathrm{T} 1$ digestion and UV cross-linking. Autoradiogram was performed at $-70^{\circ} \mathrm{C}$ for $72 \mathrm{~h}$. Lane $1,{ }^{32} \mathrm{P}-\mathrm{RNA}{ }^{\mathrm{Xbal}}$ alone;

lane 2, ${ }^{32} \mathrm{P}-\mathrm{RNA}^{\mathrm{XbaI}}$ plus RNase T1; lane 3, ${ }^{32} \mathrm{P}-\mathrm{RNA}^{\mathrm{Xbal}}$ and GBM proteins plus RNase T1; lanes 4-7, ${ }^{32} \mathrm{P}-\mathrm{RNA}^{\mathrm{Xbal}}$ plus GBM proteins plus RNase T1 plus a 30-fold (lane 4), 100-fold (lane 5), 300-fold (lane 6), or 3,000-fold (lane 7) molar excess of synthetic 80-base transcript containing four consecutive AUUUA pentameters. Molecular size standards are indicated at left. $(C)$ Formation of 120- and 44-kD RNA/protein complexes were quantitated with scanning densitometry. The relative OD ratio was plotted against the molar excess of competitor RNA.

plexes of 120, 44, and 41 kD (Figs. 2-4, 7). Second, RNase T1 mapping (Fig. 5) and antisense ODN competition studies (Fig. 6) localize the binding of the $120-\mathrm{kD}$ complex to a region near nucleotides 2186-2203 within the 3'-UTR of the human GLUT1 mRNA, while the binding of the 44-kD complex is localized to an adenosine-uridine rich region in the vicinity of nucleotides 1885-1906 of the human GLUT1 3'-UTR (Fig. 79). Given the size of the protected RNA fragments $(20 \mathrm{kD}$ or 8 $\mathrm{kD}$ ), the estimated molecular mass of the protein forming the 120 - or $44-\mathrm{kD}$ complex is 100 or $36 \mathrm{kD}$, respectively. Third, the
36-kD cytosolic protein is one of a class of adenosine-uridine binding proteins (AUBPs) (Fig. 9). Fourth, the 36-kD cytosolic protein is downregulated in human cerebral hemangioblastoma (Figs. 2 and 3), a tumor that overexpresses the GLUT1 protein (6) but is abundant in the cytosol of human GBM (a tumor that underexpresses the GLUT1 protein) (2-5).

The binding of the $100-\mathrm{kD}$ cytosolic protein present in either GBM or HB extract to nucleotides 2186-2203 of the human GLUT1 mRNA corresponds to the $77-\mathrm{kD}$ protein present in rat C6 glioma cytosol that binds to nucleotides
A

\section{$\left[{ }^{32} \mathrm{P}\right] \mathrm{RNA}^{\mathrm{Xbal}}$}

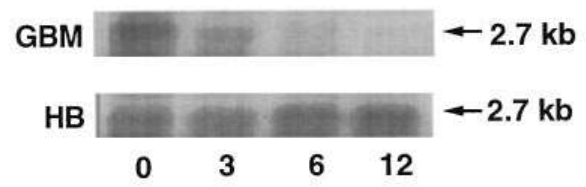

B

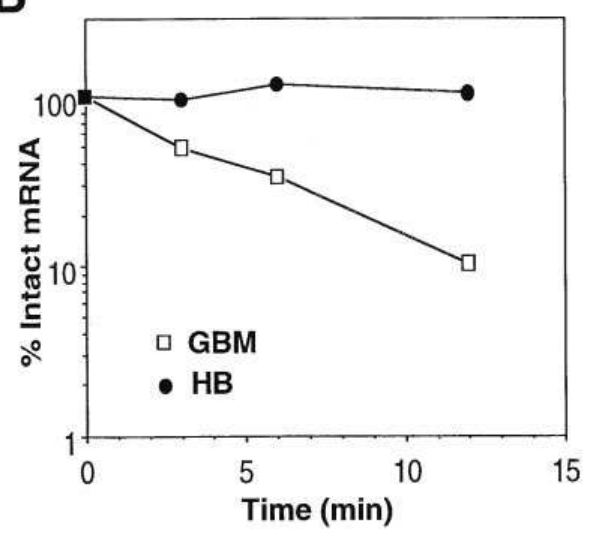

C
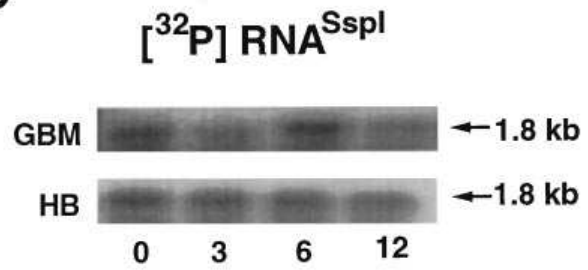

D

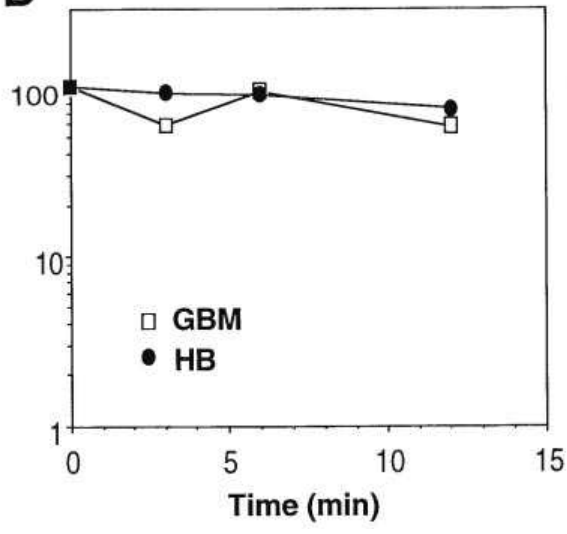

Figure 10. ( $A$ and $C$ ) Film autoradiograms of $2.7 \mathrm{~kb}^{32} \mathrm{P}-\mathrm{RNA}^{\mathrm{Xbal}}$ and $1.8 \mathrm{~kb}^{32} \mathrm{P}-\mathrm{RNA}^{\mathrm{SspI}}$ at $0,3,6$, or 12 min of incubation with GBM or HB cytosolic proteins at $37^{\circ} \mathrm{C}$. The scanning densitometric quantitation of the film autoradiograph in $A$ and $C$ are shown in $B$ and $D$, respectively. 
2180-2197 of the bovine GLUT1 mRNA (8). There is $100 \%$ conservation of a 17-mer nucleotide sequence corresponding to nucleotides 2181-2197 of the bovine GLUT1 mRNA and nucleotides 2194-2210 of the human GLUT1 mRNA and this sequence is $5^{\prime}$-CCAACCACUCAAAUUAA-3'. This sequence is unique to the GLUT1 mRNA, and cytosolic proteins that bind this domain are expressed in tumors, (e.g., human hemangioblastoma) that overexpress the GLUT1 protein (6). The hypothesis that proteins that bind this cis-element enhance GLUT1 mRNA expression is corroborated by recent studies showing that insertion of a 200-bp fragment containing nucleotides 2000-2200 of the bovine GLUT1 mRNA into the $3^{\prime}$-UTR of a luciferase expression gene results in a sixfold increase in luciferase gene expression in transfected C6 rat glioma cells (8).

The 36-kD protein binds to an AU-rich region that is predicted to reside within nucleotides 1885 and 1906 of the human GLUT1 mRNA. Binding of the protein to the GLUT1 mRNA is inhibited by an AU-rich 80-base synthetic RNA fragment (Fig. 9). The binding of this protein to GLUT1 mRNA is associated with an unusual exonuclease activity that gives a ladder pattern on RNase T1 mapping studies (Fig. 8, lane 3). There is no further degradation of the RNA upon redigestion with RNase T1 (Fig. 8, lane 4). Moreover, the fragments generated by GBM cytosol protein binding to this region of the GLUT1 mRNA do not correspond to the fragments generated by RNase T1 digestion of unprotected GLUT1 mRNA (Fig. 8, lane 2). These observations are consistent with the hypothesis that binding of a $36-\mathrm{kD}$ protein to the GLUT1 mRNA mediates the sequential action of an endonuclease and a $5^{\prime}$ - or 3 '-exonuclease at the region near nucleotides $1885-1906$. Indeed, the combined action of an endonuclease/exonuclease activity at AU-rich sequences within the $3^{\prime}$-UTR of mRNA is a recognized RNA instability determinant $(27,28)$. The hypothesis that binding of the $36-\mathrm{kD}$ protein to the GLUT1 mRNA mediates destabilization of the mRNA is in accord with the finding that the $36-\mathrm{kD}$ protein is downregulated in a human brain tumor (hemangioblastoma) that overexpresses GLUT1 (6). For example, there is no complex $\mathrm{C}$ formation, which corresponds to the $36-\mathrm{kD}$ protein, in the gel-shift mobility assay (Fig. 2), and there is decreased formation of the 44-kD complex in the UV crosslinking studies with hemangioblastoma cytosolic proteins, as compared to GBM cytosol proteins (Fig. 3). The expression of the $36-\mathrm{kD}$ protein in GBM correlates with the selective degradation of GLUT1 ${ }^{32} \mathrm{P}-\mathrm{RNA}^{\mathrm{XbaI}}$ in this tumor relative to the hemangioblastoma (Fig. 10, $A$ and $B$ ). The putative RNA instability determinant at nucleotides 1885-1906 is deleted with the production of ${ }^{32} \mathrm{P}-\mathrm{RNA}^{\mathrm{SspI}}$, and this results in comparable GLUT1 mRNA stability in the GBM or HB tumors (Fig. 10, $C$ and $D$ ).

The $36-\mathrm{kD}$ protein that binds the AU-rich region of GLUT1 mRNA has approximately the same molecular mass as GAPDH, a cytosolic enzyme that is also on the AU-rich mRNA binding protein (26). However, the level of this enzyme is comparable in either GBM or HB proteins, and the 40.10.09 $\mathrm{mAb}$ to human GAPDH does not bind to the $36-\mathrm{kD}$ protein in GBM cytosol in the GSMA (see Results). These results suggest that the $36-\mathrm{kD}$ GLUT1 mRNA binding protein in GBM cytosol is not GAPDH.

The ARE found in the $3^{\prime}$-UTR of multiple mRNAs is one class of instability element that interacts with multiple AUBPs in the cytosol, and which stabilize or destabilize the mRNA, depending on the cellular state $(16,29-32)$. Previous studies have shown that TNF- $\alpha$ induces the expression of an AUBP that binds to an ARE on rat GLUT1 3'-UTR, which increases the stability of the mRNA (33). However, in other systems, the AUBP binds to an ARE of the $c$-fos mRNA $3^{\prime}$-UTR, which facilitates removal of the poly $A$ tail and subsequent degradation of the mRNA (34). A single AUUUA pentameter (29) is present in the 3'-UTR at nucleotides 2398-2402 in bovine GLUT1 mRNA (35) or nucleotides 2409-2413 in human GLUT1 mRNA (14). This sequence is present in the GLUT1 RNA $^{\text {Xbal, but not in the GLUT1 RNA }}{ }^{\text {HindIII }}$ (Fig. 1), and, therefore, could not contribute to the formation of the $44-\mathrm{kD}$ complex shown in Figure $7 \mathrm{~B}$.

In summary, the present studies demonstrate that cytosolic proteins are differentially expressed in two human brain tumors, glioblastoma multiforme and hemangioblastoma. Both tumors express a $100-\mathrm{kD}$ cytosolic protein that binds to nucleotides 2186-2203 of the human GLUT1 mRNA. Previous studies provide evidence that this cis-element serves to augment GLUT1 gene expression (8). The present studies show that the $100-\mathrm{kD}$ protein binding to this cis-element is preserved in hemangioblastoma, a tumor that overexpresses the GLUT1 protein. A 36-kD protein binds to an AU-rich region corresponding to nucleotides 1885-1906 of the GLUT1 mRNA. The binding of this protein to the mRNA is associated with an exonuclease activity (Fig. 7). The $36-\mathrm{kD}$ protein is expressed in both GBM and in rat C6 glioma cells, which are tumors that underexpress the GLUT1 protein. Therefore, the 36-kD protein may serve to destabilize the GLUT1 mRNA by targeting an RNA instability determinant within the GLUT1 mRNA 3 '-UTR. The precise roles of the $100-$ and $36-\mathrm{kD}$ proteins in the regulation of GLUT1 mRNA may be clarified in future studies by mutation of the putative $3^{\prime}$-UTR cis sequences, and an analysis of the effects of such mutations on GLUT1 mRNA stability and gene expression.

\section{Acknowledgments}

Emily Yu skillfully prepared the manuscript. The authors are indebted to Drs. Arno Kumagai, Keijiro Sugimura, and Yasunari Saito for helpful discussions.

This work was supported by National Institutes of Health grant P01-NS-25554. Dr. Tsukamoto is supported in part by the American Diabetes Association and by the Oberkotter Foundation.

\section{References}

1. Nishioka, T., Y. Oda, Y. Seino, T. Yamamoto, N. Inagaki, H. Yano, H. Imura, R. Shigemoto, and H. Kikuchi. 1992. Distribution of the glucose transporters in human brain tumors. Cancer Res. 52:3972-3979.

2. Boado, R.J., K.L. Black, and W.M. Pardridge. 1994. Gene expression of GLUT3 and GLUT1 glucose transporters in human brain tumors. Mol. Brain Res. 27:51-57.

3. Guerin, C., J. Laterra, R.H. Hruban, H. Brem, L.R. Drewes, and G.W. Goldstein. 1990. The glucose transporter and blood-brain barrier of human brain tumors. Ann. Neurol. 28:758-765.

4. Harik, S.I., and U. Roessmann. 1991. The erythrocyte-type glucose transporter in blood vessels of primary and metastatic brain tumors. Ann. Neurol. 29: 487-491.

5. Nagamatsu, S., H. Sawa, A. Wakizaka, and T. Hoshino. 1993. Expression of facilitative glucose transporter isoforms in human brain tumors. J. Neurochem. 61:2048-2053.

6. Cornford, E.M., S. Hyman, K.L. Black, M.E. Cornford, H.V. Vinters, and W.M. Pardridge. 1995. High expression of the GLUT1 glucose transporter in human brain hemangioblastoma endothelium. J. Neuropathol. \& Exp. Neurol. 54:842-851.

7. Pardridge, W.M., and R.J. Boado. 1993. Molecular cloning and regula- 
tion of gene expression of blood-brain barrier glucose transporter. In The Blood-Brain Barrier: Cellular and Molecular Biology. W.M. Pardridge, editor. Raven Press, New York. 395-440.

8. Dwyer, K.J., R.J. Boado, and W.M. Pardridge. 1995. Cis-element/cytoplasmic protein interactions within the $3^{\prime}$-untranslated region of GLUT1 glucose transporter mRNA. J. Neurochem. 66:449-458.

9. Klausner, R.D., and J.B. Harford. 1989. Cis-trans models for post-transcriptional gene regulation. Science (Wash. DC). 246:870-872.

10. Theil, E.C. 1990. Regulation of ferritin and transferrin receptor mRNAs. J. Biol. Chem. 265:4771-4774.

11. Burd, C.G., and G. Dreyfuss. 1994. Conserved structures and diversity of functions of RNA-binding proteins. Science (Wash. DC). 265:615-621.

12. Mansur, N.R., K. Meyer-Siegler, J.C. Wurzer, and M.A. Sirover. 1993. Cell cycle regulation of the glyceraldehyde-3-phosphate dehydrogenase/uracil DNA glycosylase gene in normal human cells. Nucleic Acids Res. 21:993-998.

13. Mueckler, M., and H.F. Lodish. 1986. The human glucose transporter can insert posttranslationally into microsomes. Cell. 44:629-637.

14. Mueckler, M., C. Caruso, S.A. Baldwin, M. Panico, I. Blench, H.R. Morris, W.J. Allard, G.E. Lienhard, and H.F. Lodish. 1985. Sequence and structure of a human glucose transporter. Science (Wash. DC). 229:941-945.

15. Boado, R.J., H. Tsukamoto, and W.M. Pardridge. 1996. Evidence for translational control elements within the $5^{\prime}$-untranslated region of GLUT1 glucose transporter mRNA. J. Neurochem. In press.

16. Malter, J.S. 1989. Identification of an AUUUA-specific messenger RNA binding protein. Science (Wash. DC). 246:664-666.

17. Krieg, P.A., and D.A. Melton. 1987. In vitro RNA synthesis with SP6 RNA polymerase. Methods Enzymol. 155:397-415.

18. Boado, R.J., and W.M. Pardridge. 1992. Complete protection of antisense oligonucleotides against serum nuclease degradation by an avidin-biotin system. Bioconjugate Chem. 3:519-523.

19. Leibold, E.A., and H.N. Munro. 1988. Cytoplasmic protein binds in vitro to a highly conserved sequence in the $5^{\prime}$ untranslated region of ferritin heavy- and light-subunit mRNAs. Proc. Natl. Acad. Sci. USA. 85:2171-2175.

20. Blackburn, P., G. Wilson, and S. Moore. 1977. Ribonuclease inhibitor from human placenta. J. Biol. Chem. 252:5904-5910.

21. Kwon, Y.K., and H.N. Hecht. 1991. Cytoplasmic protein binding to highly conserved sequence in the 3 '-untranslated region of mouse protamine 2 mRNA, a translationally regulated transcript of male germ cells. Proc. Natl. Acad. Sci. USA. 88:3584-3588.

22. Kang, J.H., T.J. Yokoi, and M.J. Holland. 1995. Binding sites for abun- dant nuclear factors modulate RNA polymerase I-dependent enhancer function in saccharomyces cerevisiae. J. Biol. Chem. 270:28723-28732.

23. Nickelsen, J., and G. Link. 1989. Interaction of 3' RNA region of the mustard trnK gene with chloroplast proteins. Nucleic Acids Res. 17:9637-9648.

24. Liang, H., and J.P. Jost. 1991. An estrogen-dependent polysomal protein binds to the $5^{\prime}$ untranslated region of the chicken vitellogenin mRNA. $\mathrm{Nu}$ cleic Acids Res. 19:2289-2294.

25. Birnbaum, M.J., H.C. Haspel, and O.M. Rosen. 1986. Cloning and characterization of a cDNA encoding the rat brain glucose-transporter protein. Proc. Natl. Acad. Sci. USA. 83:5784-5788.

26. Nagy, E., and W.F. Rigby. 1995. Glyceraldehyde-3-phosphate dehydrogenase selectively binds AU-rich RNA in the NAD ${ }^{+}$-binding region (Rossman fold). J. Biol. Chem. 270:2755-2763.

27. Cole, M., and S. Mango. 1990. cis-Acting Determinants of c-myc mRNA Stability. Enzymes. 44:167-180.

28. Raue', H. 1994. Metabolic stability of mRNA in yeast-a potential target for modulating productivity? Trends Biotechnol. 12:444-449.

29. Shaw, G., and R. Kamen. 1986. A conserved AU sequence from the 3 untranslated region of GM-CSF mRNA mediates selective mRNA degradation. Cell. 46:659-667.

30. Vakalopoulou, E., J. Schaack, and T. Shenk. 1991. A 32-kilodalton protein binds to AU-rich domains in the $3^{\prime}$-untranslated regions of rapidly degraded mRNAs. Mol. Cell. Biol. 11:3355-3364.

31. Bohjanen, P.R., B. Petryniak, C.H. June, C.B. Thompson, and T. Lindsten. 1991. An inducible cytoplasmic factor (AU-B) binds selectively to AUUUA multimers in the $3^{\prime}$-untranslated region of lymphokine mRNA. Mol. Cell. Biol. 11:3288-3295.

32. Gaugitsch, H.W., E.E. Prieschl, F. Kalthoff, N.E. Huber, and T. Baumruker. 1992. A novel transiently expressed, integral membrane protein linked to cell activation. J. Biol. Chem. 267:11267-11273.

33. Stephens, J.M., B.Z. Carter, P.H. Pekala, and J.S. Malter. 1992. Tumor necrosis factor $\alpha$ induced glucose transporter (GLUT1) mRNA stabilization in 3T3-L1 preadipocytes. J. Biol. Chem. 267:8336-8341.

34. Wilson, T., and R. Treisman. 1988. Removal of poly (A) and consequent degradation of c-fos mRNA facilitated by $3^{\prime}$ AU-rich sequences. Nature (Lond.). 336:396-399.

35. Boado, R.J., and W.M. Pardridge. 1990. Molecular cloning of the bovine blood-brain barrier glucose transporter cDNA and demonstration of phylogenetic conservation of the 5'-untranslated region. Mol. Cell. Neurosci. 1:224-232. 